Грейчене Ирма Витаутовна

магистрант

Шиирас Шарунас

д-р пед. наук, доцент

Литовский университет спорта

г. Каунас, Литовская Республика

DOI $10.21661 / r-116482$

\title{
EVALUATION OF SOCIAL SKILLS OF THE UPPER CLASS SECONDARY SCHOOL STUDENTS
}

Аннотация: в данной статье речь идет о том, что недостаточно развитые коммуникативные навыки учеников старших классов средней школь являются причиной трудностей при общении в различных ситуащиях повседневной жизни. Таким образом, в этой работе проанализировано умение старшеклассников общаться в различных ситуачиях повседневной жизни.

Ключевые слова: студенты, девушки, парни, коммуникативные навыки.

Abstract: it is specified in the article that a lack of situational social skills in daily life situations imply a significant problem for school-age students. Therefore, this paper is intended to evaluate how situational social skills of upper class secondary school students are evaluated.

Keywords: students, girls, boys, social skills.

Over the past thirty years the scientists of foreign countries working in the educational system pay much attention on preparation of children and teens for life in a complex society [2;4]. This concern of scientists is revealed by arising psychosocial problems of children and teens. In order to solve these problems more attention should be paid on social skills development [4]. Namely formulation of situational social skills allows students to manage social situations, to deal effectively with true-life problems, to adapt successfully in a new changing environment and to affect the environment accordingly or even change it $[1 ; 3]$. There is also no doubt that situational social skills determine a quality of management of social situations by a young personality and a 
quality of social functioning of young people, strongly influence their personal and public life. The student who has and applies social skills can meet the needs, communicate effectively, protect himself/herself, agree with others, is able to interact with others in various daily life situations. Since a lack of social skills usually causes long-term and short-term difficulties in various fields, especially in educational field, it is important to analyse situational social skills as one of the most important indicators of social competence of personality. This is practically beneficial because it allows development of various social behaviour programs. In order to prepare the programs of social skills development that are suitable for students first of all we sought to find out a level of situational social skills of female and male students. There is a lack of such studies. Therefore, this leads to a problematic question: how situational social skills of students are evaluated?

A questionnaire of E. Gambrill (1995) [quoted from 2], that was specially adapted by us, is applied for evaluation of situational social skills. The following social skills are given in the adapted questionnaire: ability to refuse, reacting to remarks, ability to contradict, apology, recognition of being wrong, ability to enjoy praise at own address, ability to start a conversation, ability to talk, to end a conversation, to ask for help, to say good words, to talk about own feelings. Each skill is evaluated in the scale of five points: 1-2 points correspond to a low level of situational skills, 3-4 points correspond to an average level and 5 points correspond to a high level of situational social skills.

Organising of the research. The sample of the research subjects has been selected in a comfortable way. The research has been carried out in two Kaunas urban schools and in two Kaunas rural schools. The 15 to 18 years old upper class secondary school students took part in the survey: 62 students from schools of Kaunas urban (27 girls and 35 boys) and 56 students from Kaunas rural schools (26 girls and 30 boys). The research has been conducted in November 2016 at schools during class meetings after having agreed in advance with class tutors and administration of the institutions.

The research results show that students of urban and rural schools (girls and boys) statistically reliably differed in accordance with the following situational social skills: ability to refuse $(\mathrm{p}<0,05)$, ability to enjoy praise at own address $(\mathrm{p}<0,05)$, to say good 
words $(\mathrm{p}<0,05)$, to talk about own feelings $(\mathrm{p}<0,05)$. It should be noted that the upper level of one part of situational skills is typical for female and the upper level of other part of situational skills is typical for male secondary school students. For example, female students more often evaluated the level of skills to talk about own feelings $(64,2 \%)$, to say good words $(58,5 \%)$ as high. Whereas boys gave much higher evaluation to the skill ability to contradict (46,2\% of male students evaluated this skill as high). However, evaluations of female and male secondary school students statistically did not differ in accordance with the following situational social skills: ability to refuse, to react to remarks, to apologize, to recognise of being wrong, to start a conversation, to be able to talk, to the able to end a conversation.

Table 1

Statistical indicators of situational social skills of the students (girls and boys) of urban and rural schools

\begin{tabular}{|c|c|c|c|c|c|c|c|c|}
\hline \multirow{3}{*}{ SOCIAL SKILLS } & \multirow{3}{*}{ Gender } & \multicolumn{6}{|c|}{ Level } & \multirow{3}{*}{$\begin{array}{l}\chi^{2}(2) \\
\quad p\end{array}$} \\
\hline & & \multicolumn{2}{|c|}{ Low } & \multicolumn{2}{|c|}{ Average } & \multicolumn{2}{|c|}{ High } & \\
\hline & & $n$ & $\%$ & $n$ & $\%$ & $n$ & $\%$ & \\
\hline \multirow{2}{*}{ To be able to refuse } & Girls & 16 & 30,2 & 17 & 32,1 & 20 & 37,7 & \multirow{2}{*}{$\begin{array}{c}4,54 \\
p>0,05\end{array}$} \\
\hline & Boys & 10 & 15,4 & 20 & 30,8 & 35 & 53,8 & \\
\hline \multirow{2}{*}{ To react to remarks } & girls & 14 & 26,4 & 18 & 34,0 & 21 & 39,6 & \multirow{2}{*}{$\begin{array}{c}1,46 \\
p>0,05\end{array}$} \\
\hline & boys & 12 & 18,5 & 21 & 32,3 & 32 & 49,2 & \\
\hline \multirow{2}{*}{ To be able to contradict } & girls & 11 & 20,8 & 28 & 52,8 & 14 & 26,4 & \multirow{2}{*}{$\begin{array}{c}6,02 \\
p<0,05\end{array}$} \\
\hline & boys & 14 & 21,5 & 21 & 32,3 & 30 & 46,2 & \\
\hline \multirow{2}{*}{ To apologize } & girls & 17 & 32,1 & 25 & 47,1 & 11 & 20,8 & \multirow{2}{*}{$\begin{array}{c}3,94 \\
p>0,05\end{array}$} \\
\hline & boys & 23 & 35,4 & 20 & 30,8 & 22 & 33,8 & \\
\hline \multirow{2}{*}{$\begin{array}{l}\text { To recognise of being } \\
\text { wrong }\end{array}$} & girls & 19 & 35,8 & 24 & 45,3 & 10 & 18,9 & \multirow{2}{*}{$\begin{array}{c}3,29 \\
p>0,05\end{array}$} \\
\hline & boys & 23 & 35,4 & 21 & 31,3 & 21 & 31,3 & \\
\hline \multirow{2}{*}{ To be able to enjoy praise } & girls & 5 & 9,3 & 9 & 16,9 & 37 & 69,8 & \multirow{2}{*}{$\begin{array}{l}13,97 \\
p<0,05\end{array}$} \\
\hline & boys & 15 & 23,8 & 26 & 41,3 & 22 & 34,9 & \\
\hline \multirow{2}{*}{ To start a conversation } & girls & 23 & 43,4 & 14 & 26,4 & 16 & 30,2 & \multirow{2}{*}{$\begin{array}{c}2,56 \\
p>0,05\end{array}$} \\
\hline & boys & 19 & 29,2 & 21 & 32,3 & 25 & 38,5 & \\
\hline \multirow{2}{*}{ To be able to talk } & girls & 4 & 7,5 & 33 & 62,3 & 16 & 30,2 & \multirow{2}{*}{$\begin{array}{c}1,22 \\
\mathrm{p}>0,05\end{array}$} \\
\hline & boys & 7 & 10,8 & 34 & 52,3 & 24 & 36,9 & \\
\hline \multirow{2}{*}{$\begin{array}{l}\text { To be able to end a con- } \\
\text { versation }\end{array}$} & girls & 14 & 26,4 & 13 & 24,5 & 26 & 49,1 & \multirow{2}{*}{$\begin{array}{c}3,07 \\
p>0,05\end{array}$} \\
\hline & boys & 17 & 26,1 & 25 & 38,5 & 23 & 35,4 & \\
\hline To ask for help & girls & 18 & 34,0 & 14 & 26,4 & 21 & 36,6 & 3,78 \\
\hline
\end{tabular}




\begin{tabular}{|l|l|cc|cc|cc|c|}
\hline & boys & 15 & 24,6 & 27 & 41,5 & 22 & 33,9 & $\mathrm{p}>0,05$ \\
\hline \multirow{2}{*}{ To say good words } & girls & 10 & 18,9 & 12 & 22,6 & 31 & 58,5 & $\begin{array}{c}8,55 \\
\end{array}$ \\
\cline { 2 - 7 } & boys & 24 & 36,9 & 20 & 30,8 & 21 & 32,3 & $p<0,05$ \\
\hline \multirow{2}{*}{ To tell what one feels } & girls & 8 & 15,1 & 11 & 20,7 & 34 & 64,2 & $\begin{array}{c}9,87 \\
\end{array}$ \\
\cline { 2 - 6 } & boys & 15 & 23,1 & 27 & 41,5 & 23 & 35,4 & $p<0,05$ \\
\hline
\end{tabular}

Both girls and boys evaluated a level of aforementioned situational social skills as average. Therefore, it can be supposed that behaviour of female and male students would not differ in various daily life situations.

Conclusions. The results showed that situational social skills of female students are of statistically reliably $(\mathrm{p}<0,05)$ higher level compared to male students in accordance with the following skills: to talk about own feelings, to say good words, to be able to enjoy praise at own address. Whereas boys are much more $(\mathrm{p}<0,05)$ able to refuse.

\section{References}

1. Cohen J.A. unique adolescent response to reward prediction errors / R. Asarnow, F. Sabb, R. Bilder, S. Bookheimer [etc.] // Nature neuroscience. - 2010. Vol. 43. - №13-6. - P. 669-671.

2. Hinsch R. Gruppenttaining sozialer Kompetenzen (3 Aufl.) / R. Hinsch, U. Pfingsten. - Weinheim: Beltz, 1998. - 89 p.

3. Holopainen L. The role of social competence in the psychological well-being of adolescents in secondary education / L. Holopainen // Scandinavian Journal of Educational Research. - 2012. - №56(2). - P. 199-212.

4. Gresham M.F. Social behavioral assessment and intervention: observations and impressions / M.F. Gresham // School psychology review. - 2011 . - №40(2) . - P. 275283. 